\title{
Nowy model organizacji i funkcjonowania starych przedsiębiorstw przemyslowych
}

\author{
RESTRUKTURYZACJA PRZEDSIĘBIORSTW PRZEMYSŁOWYCH \\ JAKO PRZEDMIOT BADAŃ GEOGRAFII PRZEMYSŁU
}

Proces transformacji systemu społeczno-gospodarczego w Polsce, zapoczątkowany w 1989 roku spowodował szereg radykalnych zmian w funkcjonowaniu przedsiębiorstw przemysłowych. W wyniku tego procesu przedsiębiorstwa uzyskały swobodę w decydowaniu o wyborze dróg rozwoju, ale jednocześnie stały się bardziej zależne od otoczenia. Zmiany $\mathrm{w}$ polskich przedsiębiorstwach przemysłowych są bowiem naturalnym następstwem zmian wynikających z transformującej się gospodarki kraju, a zwłaszcza z takich elementów przemian ustrojowych, jak [Stadtherr 1997: 213; Tobolska 2004: 17]: przekształcenia własnościowe, nowe, odmienne mechanizmy alokacji kapitału, obiektywizacja parametrów ekonomicznych, rynkowa weryfikacja efektywności gospodarowania, a także otwarcie na wpływy gospodarki światowej. Charakter zmian zachodzących w przedsiębiorstwach przemysłowych jest wielopłaszczyznowy i obejmuje wszystkie wymiary ich funkcjonowania. Splot tych zmian, ich radykalny charakter oraz stosunkowo krótki okres ich przebiegu pozwala uznać je za przejaw restrukturyzacji przedsiębiorstw w ujęciu R. Szula, a także H. Singha [Sapijaszka 1996: 28].

Transformacja gospodarki polskiej stwarza szczególnie interesujące pole do badania przeobrażeń w przedsiębiorstwach przemysłowych, a zwłaszcza tych największych, które w gospodarce centralnie sterowanej posiadały główne priorytety rozwoju. Wydaje się, że w pierwszym etapie transformacji to właśnie w nich najwyraźniej odzwierciedliły się kluczowe problemy polskiego przemysłu: obciążenie ogromnym balastem zbędnych środków produkcji (np. wyposażenie, powierzchnia), przerostem zatrudnienia, przestarzałą strukturą produkcji, co w zderzeniu z nowymi realiami ujawniło skalę potrzebnych przeobrażeń. Ponadto duże przedsiębiorstwa właśnie ze względu na swoją wielkość posiadają dobrze wykształcone struktury organizacyjne, co ułatwia identyfikację zmian. Analizując więc zmiany zachodzące w dużych polskich przedsiębiorstwach przemysłowych, utożsamiane z ich restrukturyzacją, starano się zwrócić szczególną uwagę na mechanizm zmian organizacyjnych jako jeden z głównych wymiarów adaptacji przedsiębiorstw przemysłowych do nowych reguł gospodarowania, pociagający za sobą kształtowanie się nowych relacji przestrzennych. Według J. Majchrzak [2001: 98] ,zmiany organizacyjne stanowią istotny kierunek, a zarazem warunek przystosowania przedsiębiorstw do działania w gospodarce rynkowej”. W analizie tej 
starano się wykorzystać aparat pojęciowy z zakresu nauki o organizacji i zarządzaniu, jako dziedziny zajmującej się zmianami w organizacjach, co w rezultacie w dużej mierze zadecydowało o charakterze przeprowadzonej analizy. Na powiązania nurtu geografii przedsiębiorstw z dorobkiem współczesnej teorii organizacji zwracał uwagę B. Domański [1997], charakteryzując go jako nurt interdyscyplinarny i powiązany z innymi naukami społecznymi. Jego prekursorami byli Robert McNee i G. Krumme, którzy rozpoczęli badania przedsiębiorstw w kategoriach aktywnego podmiotu funkcjonującego w przestrzeni. B. Domański zwrócił również uwagę na potrzebę rozwijania badań nad współczesnymi przedsiębiorstwami w Polsce, a przede wszystkim nad tym, jak zachowania przedsiębiorstw w zmienionych warunkach gospodarczych rzutują na przestrzenną organizację działalności gospodarczej oraz w jaki sposób wpływają na gospodarkę i społeczności lokalne. Według cytowanego autora potrzeba ta wynika z faktu, iż to właśnie przedsiębiorstwa (autor używa terminu: „firmy”) „są kluczowym ośrodkiem podejmowania decyzji, w których kształtują się strategie i decyduje się organizacja systemu produkcji i usług, w tym także w wymiarze przestrzennym. Zrozumienie funkcjonowania i rozwoju przedsiębiorstw jest niezbędne dla zrozumienia przestrzennej organizacji działalności gospodarczej" [1977: 102]. Nurt geografii przedsiębiorstw stanowi więc ważny aspekt mikroekonomiczny dotychczasowych studiów geograficznych dotyczących transformacji przemysłu w Polsce.

Dla empirycznej ilustracji zachodzących zmian posłużono się przykładami restrukturyzacji właśnie dużych przedsiębiorstw przemysłowych, takich jak: H. Cegielski Poznań S.A., SKF Poznań S.A. (przed prywatyzacją w 1995 roku Fabryka Łożysk Tocznych), „LECH” Browary Wielkopolski S.A. (obecnie Kompania Piwowarska S.A.), Wielkopolskie Tartaki „Witar”, Poznańskie Zakłady Farmaceutyczne „Polfa” S.A. (po prywatyzacji w 1998 r. Glaxo Wellcome, obecnie GlaxoSmith Kline). Zakres czasowy analizy dotyczy dekady lat 90., a więc okresu najbardziej intensywnych zmian restrukturyzacyjnych w tych przedsiębiorstwach.

\section{ZMIANY W ORGANIZACJI PRZEDSIĘBIORSTW PRZEMYSŁOWYCH}

Analiza zmian zachodzących w dużych przedsiębiorstwach przemysłowych skoncentrowana została w pierwszym rzędzie na rozpoznaniu zmian w organizacji badanych przedsiębiorstw, w tym zwłaszcza zmian ich struktur i wskaźników opisujących te struktury. Podstawą analizy przemian struktur organizacyjnych przedsiębiorstw przemysłowych jest wyróżnienie pewnych charakterystyk strukturalnych, a więc cech opisu struktur, które pozwolą stwierdzić różnice w strukturach wybranych przedsiębiorstw, w różnych momentach czasowych [por. Przybyła 1996: 19-32]. Dla potrzeb niniejszego artykułu posłużono się dwoma wybranymi charakterystykami struktur organizacyjnych przedsiębiorstw:

- pierwsza charakterystyka dotyczyła funkcji wyspecjalizowanych jednostek organizacyjnych, czyli specjalizacji, przy czym pomiaru specjalizacji dokonano na podstawie koncepcji zaproponowanej przez Pugha i Kiesera, a przedstawionej w pracy M. Przybyły [1996: 33] oraz A. Tobolskiej [2004],

- druga charakterystyka związana była ze sposobem wyodrębniania podstawowych jednostek organizacyjnych przedsiębiorstw, co stało się podstawą do wyróżnienia kilku rodzajów struktur: funkcjonalnych, obiektowych, regionalnych, hybrydowych oraz struktur koncernowych i holdingowych ugrupowań gospodarczych. 
Ponadto istotnym elementem w restrukturyzacji przedsiębiorstw przemysłowych było tworzenie odrębnych działów marketingu odpowiedzialnych za kształtowanie relacji przedsiębiorstwa z klientami, co można traktować jako przejaw zmiany orientacji przedsiębiorstw przemysłowych z produkcyjnej na rynkową. Z kolei jednym z najbardziej widocznych i najbardziej odczuwalnych społecznie skutków restrukturyzacji przedsiębiorstw są zmiany wielkości zatrudnienia, a w przypadku starych i dużych przedsiębiorstw najczęściej jednak jego redukcje.

Na podstawie wyników badań empirycznych wyróżniono wiele cech, charakteryzujących zmiany organizacyjne zachodzące w wybranych dużych przedsiębiorstwach przemysłowych (tab. 1).

Tabela 1. Charakterystyczne zmiany w wybranych dużych przedsiębiorstwach przemysłowych

\begin{tabular}{|l|c|c|c|c|c|}
\hline \multicolumn{1}{|c|}{ Zmiana cechy 1990-2000 } & „HCP” & „LECH” & „Polfa” & $\begin{array}{c}\text { FŁT S.A. } \\
- \text { SKF }\end{array}$ & ,Witar" \\
\hline $\begin{array}{l}\text { Struktura organizacyjna: } \\
\text { ewolucja struktury organizacyjnej }\end{array}$ & + & + & + & + & + \\
\hline $\begin{array}{l}\text { Specjalizacja struktury organizacyjnej: spadek } \\
\text { wartości wskaźników specjalizacji }\end{array}$ & + & + & - & - & + \\
\hline $\begin{array}{l}\text { Outsourcing: } \\
\text { eksternalizacja niektórych funkcji } \\
\text { przedsiębiorstwa }\end{array}$ & + & + & + & + & + \\
\hline $\begin{array}{l}\text { Spin-offs: } \\
\text { tworzenie przez pracowników odrębnych spółek }\end{array}$ & + & + & - & + & + \\
\hline $\begin{array}{l}\text { Koncentracja zewnętrzna: } \\
\text { integracja organizacyjna }\end{array}$ & - & + & + & + & - \\
\hline $\begin{array}{l}\text { Koncentracja wewnętrzna: } \\
\text { decentralizacja zarządzania i dezintegracja } \\
\text { pionowa poprzez autonomizacjęjednostek } \\
\text { organizacyjnych }\end{array}$ & + & + & + & + & + \\
\hline $\begin{array}{l}\text { Marketing: } \\
\text { wzrost znaczenia i powstanie odrębnych } \\
\text { działów marketingu }\end{array}$ & + & + & + & + & + \\
\hline $\begin{array}{l}\text { Wielkość zatrudnienia: } \\
\text { redukcje liczby pracowników }\end{array}$ & + & + & - & + & + \\
\hline
\end{tabular}

Źródło: opracowanie własne

„," zmiana cechy wystąpiła, ,, - "zmiana cechy nie wystapiła

Do najistotniejszych cech charakteryzujących te zmiany można zaliczyć:

- ewolucję struktur organizacyjnych poprzez autonomizację jednostek organizacyjnych,

- spadek wartości wskaźników specjalizacji, głównie w wyniku procesów eksternalizacji niektórych funkcji przedsiębiorstwa, co z kolei związane było z tworzeniem przez byłych pracowników odrębnych spółek,

- procesy koncentracji wewnętrznej i zewnętrznej,

- powstawanie odrębnych działów marketingu,

- zmniejszenie liczebności załóg przedsiębiorstw. 
Do zasadniczych zmian w przedsiębiorstwach przemysłowych można zaliczyć ewolucję ich struktur organizacyjnych, od funkcjonalnych poprzez obiektowe i regionalne ku strukturom koncernowym i holdingowym ugrupowań gospodarczych, głównie w wyniku autonomizacji jednostek organizacyjnych. Wyróżnione typy struktur (funkcjonalne, obiektowe, regionalne) układają się w łańcuch ewolucji rozwiązań organizacyjnych, przedstawiony na gruncie nauk z zakresu organizacji i zarządzania [por. Koziński 1996: 170; Tobolska 2004: 92].

Wraz z rosnącą złożonością ekonomiczną i społeczną otoczenia przedsiębiorstw, zaostrzającą się konkurencją i coraz bardziej odmiennymi potrzebami poszczególnych segmentów rynku zbytu, w przedsiębiorstwach następuje ewolucja rozwiązań organizacyjnych w kierunku autonomizacji jednostek organizacyjnych, zwana w teorii organizacji i zarządzania dywizjonalizacją struktur organizacyjnych. Na oznaczenie tego procesu B. Domański [1992: 66] używa terminu fragmentacji struktur organizacyjnych, a G. Nizard [1998: 143] atomizacji struktur. Autonomizacja jednostek organizacyjnych polega na wyodrębnianiu się w ramach dużego przedsiębiorstwa względnie samodzielnych jednostek, które ewoluują od statusu jednostek wykonawczych do statusu jednostek gospodarczych, posiadających osobowość prawną. Zwarte na początku przedsiębiorstwo traci tym samym swoją spoistość i przybiera formę ugrupowania gospodarczego. Proces ten jest wynikiem dużej koncentracji organizacyjnej, charakterystycznej dla dużych przedsiębiorstw przemysłowych oraz ich dążenia do decentralizacji zarządzania, a tym samym zmniejszenia ryzyka działalności gospodarczej. Autonomizacja związana jest więc $\mathrm{z}$ decentralizacją oraz dezintegracją pionową organizacji przedsiębiorstw oraz z wydzielaniem ze struktur przedsiębiorstwa samodzielnych podmiotów gospodarczych.

We wszystkich analizowanych przedsiębiorstwach przemysłowych zmiany struktur organizacyjnych przebiegały zgodnie z koncepcją ewolucji struktur, co oznacza, że wraz ze wzrostem wielkości przedsiębiorstwa, obszaru jego działania i dywersyfikacją jego produkcji następowały ich zmiany, od struktur funkcjonalnych przez obiektowe i regionalne ku strukturom holdingowym ugrupowań gospodarczych. Na początku lat 90. prawie wszystkie z badanych przedsiębiorstw miały struktury organizacyjne jednowymiarowe, czyli że w ich kształtowaniu dominowało jedno z kryteriów: funkcjonalne, bądź obiektowe, bądź regionalne (tab. 2). Jedynie struktura organizacyjna Zakładów Przemysłu Metalowego H. Cegielski - Poznań (największego do połowy lat 90. przedsiębiorstwa przemysłowego w Poznaniu) była tak bardzo rozbudowana, że przyjmowała układ struktury hybrydowej. Oznacza to, że występowały w niej nie tylko jednostki organizacyjne obiektowe, wyodrębnione na podstawie asortymentu produkcji, ale również jednostki regionalne, wyodrębnione ze względu na usytuowanie przestrzenne poza siedzibą główną tego przedsiębiorstwa (np. odlewnia żeliwa w Śremie, oddziały w Wagrowcu i Skokach).

Zmiany w strukturze organizacyjnej H. Cegielski Poznań S.A. są przykładem ewolucji struktury hybrydowej ku strukturze koncernowej, poprzez autonomizację jednostek organizacyjnych przedsiębiorstwa i nadanie im samodzielności organizacyjno-prawnej (ryc. 1, 2). Po przekształceniu w 1995 roku w jednoosobową spółkę Skarbu Państwa, nowa strategia spółki zakładała jej dalszą prywatyzację poprzez znalezienie inwestora strategicznego, dysponującego kapitałem dla sfinansowania programu modernizacji majątku produkcyjnego, technologii, maszyn i urządzeń wytwórczych. Pierwszym krokiem jej realizacji stało się wydzielenie poszczególnych części przedsiębiorstwa w odrębne podmioty gospodarcze (spółki z o.o.) i skupienie produkcji w najważniejszych dla zakładu fabrykach z sektora silnikowego. Te strategiczne zmiany w organizacji zakładu wynikały ze zmniejszenia popytu na pewne 
grupy wyrobów, z trudności w znalezieniu rynków zbytu, niskiego wykorzystania majątku niektórych fabryk - koszty stałe związane z funkcjonowaniem fabryk stanowiły znaczny udział w kosztach ogółem, przez co obniżała się konkurencyjność produkcji. Zmiany organizacyjne miały na celu poprawę efektywności posiadanego majątku i zmniejszenie kosztów działalności, również poprzez wydzielenie i usamodzielnienie działów pomocniczych i usługowych oraz związane z tym wygospodarowanie obiektów (budynków, maszyn, urządzeń), które jako zbędne dla spółki mogły zostać sprzedane lub wydzierżawione.

Tabela 2. Charakterystyki struktur organizacyjnych wybranych przedsiębiorstw przemysłowych Poznania

\begin{tabular}{|c|c|c|c|c|}
\hline \multirow[t]{2}{*}{ Przedsiębiorstwo } & \multicolumn{2}{|c|}{$\begin{array}{c}\text { Wskaźnik } \\
\text { specjalizacji Z }\end{array}$} & \multicolumn{2}{|c|}{$\begin{array}{l}\text { Rodzaj struktury wg kryterium wyodrębniania } \\
\text { jednostek organizacyjnych }\end{array}$} \\
\hline & A & B & $\mathrm{A}$ & B \\
\hline „HCP” & 1.00 & 0.75 & hybrydowa & obiektowa i koncernowa \\
\hline „LECH” & 1.00 & 0.94 & regionalna & hybrydowa i holdingowa \\
\hline „Polfa” & 1.00 & 1.00 & funkcjonalna & hybrydowa \\
\hline FŁT/ SKF & 1.00 & 0.88 & funkcjonalna & obiektowa \\
\hline „Witar” & 0.94 & 0.75 & regionalna & regionalna i koncernowo-holdingowa \\
\hline
\end{tabular}

A - przed komercjalizacją

B - po przekształceniach własnościowych

Źródło: opracowanie własne

Powstałe spółki stały się osobnymi podmiotami gospodarczymi, świadczącymi na rzecz spółki-matki pewne funkcje na mocy zawartych z nią porozumień i umów. Aby umożliwić swoim spółkom działalność, HCP S.A. wniosła do każdej z nich aport rzeczowy, w formie środków nietrwałych, i finansowy, natomiast środki trwałe zostały przekazane w dzierżawę. Każda z nowych spółek musiała ponadto opracować własny regulamin organizacyjny i status. Zmiany organizacyjne rozpoczęto w 1996 roku połączeniem dwóch fabryk: W6 (Fabryka Narzędzi) z W7 (Fabryka Wyrobów Precyzyjnych). Na bazie wydziału energetyczno-remontowego utworzono trzy spółki z o.o.: Remocentrum, Energocentrum i Infocentrum - ta ostatnia spółka przejęła należącą do wydziału centralę telefoniczną i związane $\mathrm{z}$ tym usługi telekomunikacyjne. Z Zakładu Usług Magazynowo-Transportowych utworzono spółkę Logocentrum, świadczącą od tej pory usługi magazynowe na rzecz „HCP”, a zakładową bazę transportową zlikwidowano sprzedając samochody ciężarowe byłym pracownikom, którzy podjęli działalność gospodarczą na własny rachunek i rozpoczęli świadczenie usług transportowych na rzecz spółki macierzystej. Ponadto do Fabryki Urządzeń Mechanicznych W5 przeniesiono pozostałości po Fabryce Obrabiarek W4, a z połączenia Fabryki Wyrobów Kutych i Tłoczonych W1 oraz kuźni W8 powstała spółka Plasmet, która zajmuje się produkcją butli gazowych i części samochodowych (w 2002 została sprzedana przez holding). Powstały również spółki: Service, która m.in. świadczy usługi naprawcze, doradztwo techniczne w eksploatacji i obsłudze silników morskich i kolejowych, oraz Centrum BadawczoRozwojowe, powstałe na bazie byłego Zakładu Badań, Zakładu Konstrukcji i Laboratorium Centralnego. Zlikwidowano natomiast Zakład Usług Socjalno-Bytowych, powstały w 1989 roku z potężnego (zatrudniającego 300 osób) działu socjalnego i na powrót włączono go na poziom centralnych komórek organizacyjnych przedsiębiorstwa. W ostatnim etapie reorganizacji wydzielone zostały fabryki W9 oraz W3 i przekształcone w spółki: Fabrykę Silników 
Agregatowych i Trakcyjnych oraz Fabrykę Pojazdów Szynowych. Ta ostatnia powstała w kwietniu 1999 roku po zakończonych fiaskiem próbach znalezienia dla niej nabywcy oraz w wyniku braku zleceń i zamówień na jej produkcję, która stawała się coraz bardziej nierentowna. Jako samodzielna już spółka próbowała pozyskać zamówienia na produkcję wagonów dla poznańskiego „szybkiego tramwaju”, co nie powiodło się i obecnie Poznań próbuje uratować ją przed bankructwem i przejąć jako miejski zakład naprawczy taboru kolejowego.

Tworzenie przez spółkę H. Cegielski - Poznań S.A. spółek z ograniczoną odpowiedzialnością miało doprowadzić do zasadniczej zmiany mechanizmów zarządzania tak dużym przedsiębiorstwem, o silnie zróżnicowanym asortymencie. Cechą tych zmian było odejście od zarządzania metodami administracyjnymi na rzecz zarządzania przez kapitał z wykorzystaniem uprawnień właścicielskich, będących w dyspozycji HCP S.A. Wszystkie utworzone spółki z o.o. mają bowiem charakter spółek zależnych od HCP S.A., który jest ich wyłącznym udziałowcem. Przedstawione zmiany znacznie upraszczają dotychczasową strukturę organizacyjną przedsiębiorstwa i pozwalają skoncentrować się na podstawowych dziedzinach działalności realizowanych w fabrykach: W2 Silników Okrętowych, W5 Urządzeń Mechanicznych, W7 Wyrobów Precyzyjnych oraz na działaniach prowadzących do ich prywatyzacji.

Zmiany struktury organizacyjnej spowodowały też zmiany w organizacji przestrzennej przedsiębiorstwa. Już w 1994 roku usamodzielniła się całkowicie Odlewnia Żeliwa w Śremie, zrezygnowano również z działalności oddziałów zamiejscowych fabryk W2 i W3 w Wagrowcu i w Skokach, a placówki serwisowe w Warszawie, Gdańsku i Szczecinie podlegają już jednej z wydzielonych spółek, Service. Tak więc lokalizacja spółki HCP S.A. zawężona została do terenów w granicach miasta Poznania, przy ul. 28 czerwca 1956 roku (W2 i W7) oraz przy ulicy Zamenhofa (W5), co również odpowiada założeniom strategicznym firmy, mianowicie ograniczeniu kosztów stałych przez kumulację produkcji na mniejszym obszarze. Zmiany w strukturze organizacyjnej HCP S.A. są przykładem ewolucji struktury hybrydowej ku strukturze koncernowej, poprzez autonomizację jednostek organizacyjnych przedsiębiorstwa i nadanie im samodzielności organizacyjno-prawnej.

Kolejną istotną zmianą w restrukturyzowanych przedsiębiorstwach jest zmniejszenie specjalizacji struktur organizacyjnych, wyrażonej spadkiem wartości wskaźników specjalizacji (tab. 2). Do obliczenia wskaźnika specjalizacji zastosowano funkcjonalną koncepcję pomiaru specjalizacji Pugha i Kiesera, przedstawioną w pracy M. Przybyły [1996: 33]. Zgodnie $\mathrm{z}$ tą koncepcją badano występowanie w strukturze organizacyjnej przedsiębiorstw wyspecjalizowanych komórek lub stanowisk reprezentujących 16 wyspecjalizowanych funkcji zaproponowanych przez autorów [por. Tobolska 2004: 87, 88]. Opierając się więc na tym kryterium, zmiany wskaźników specjalizacji sprowadzają się do zmian w funkcjonowaniu (lub niefunkcjonowaniu) wybranych 16 komórek organizacyjnych. Wartości wskaźników specjalizacji nie zawsze jednak odzwierciedlają zachodzące zmiany organizacyjne, szczególnie w przypadku dużych przedsiębiorstw przemysłowych o wielu wyspecjalizowanych funkcjach. Przykładem może być „Polfa”, w której wskaźnik specjalizacji nie zmienił się w badanym okresie, choć w przedsiębiorstwie zaszły istotne zmiany organizacyjne, związane zarówno z dostosowaniem do nowych warunków gospodarki rynkowej, jak i ze zmianą właściciela tego przedsiębiorstwa. Tak więc zastosowanie funkcjonalnej koncepcji pomiaru specjalizacji Pugha i Kiesera, zawęża pole badania zmian struktur organizacyjnych i dla lepszego ich rozpoznania wymaga zastosowania dodatkowych kryteriów. 


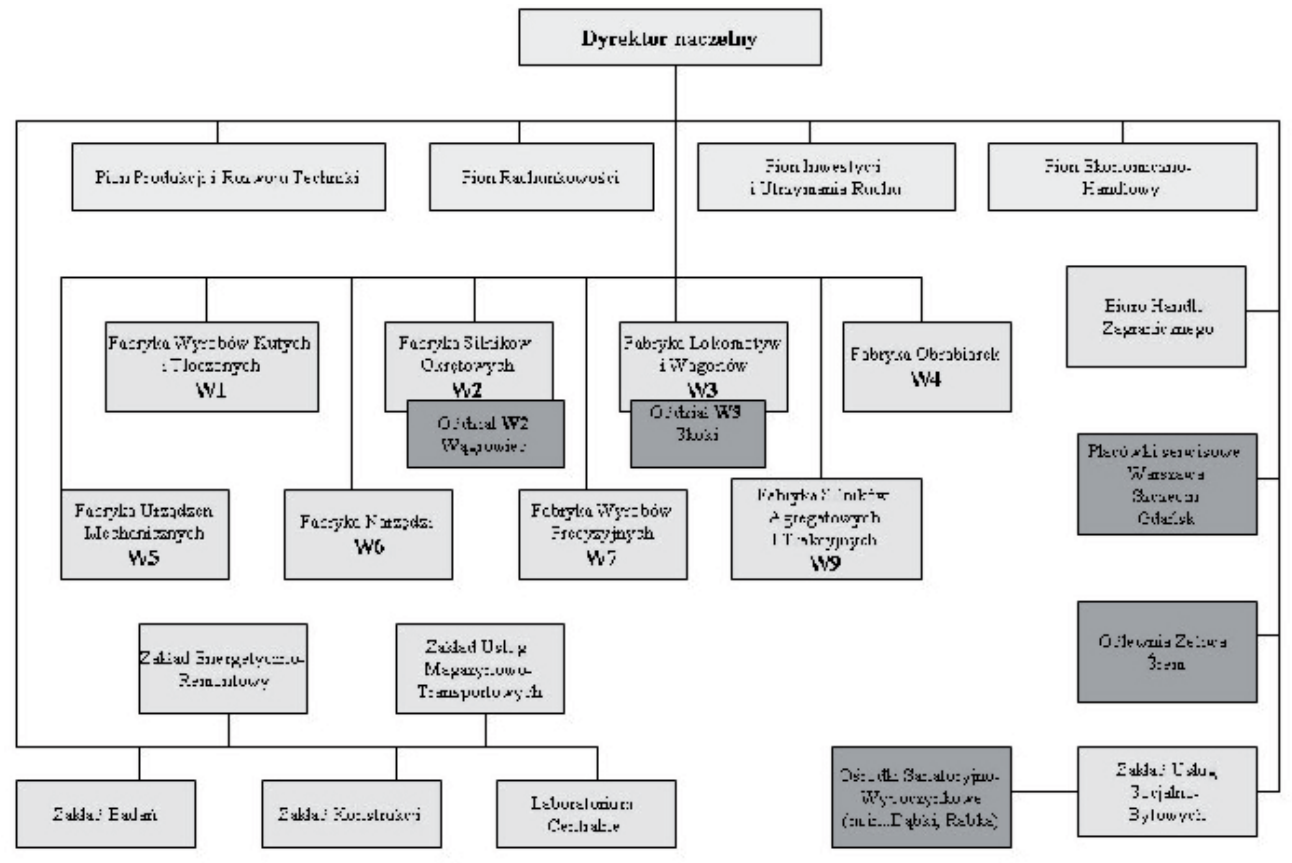

Ryc. 1. Struktura organizacyjna Zakładów Przemysłu Metalowego H. Cegielski Poznań w 1990 roku

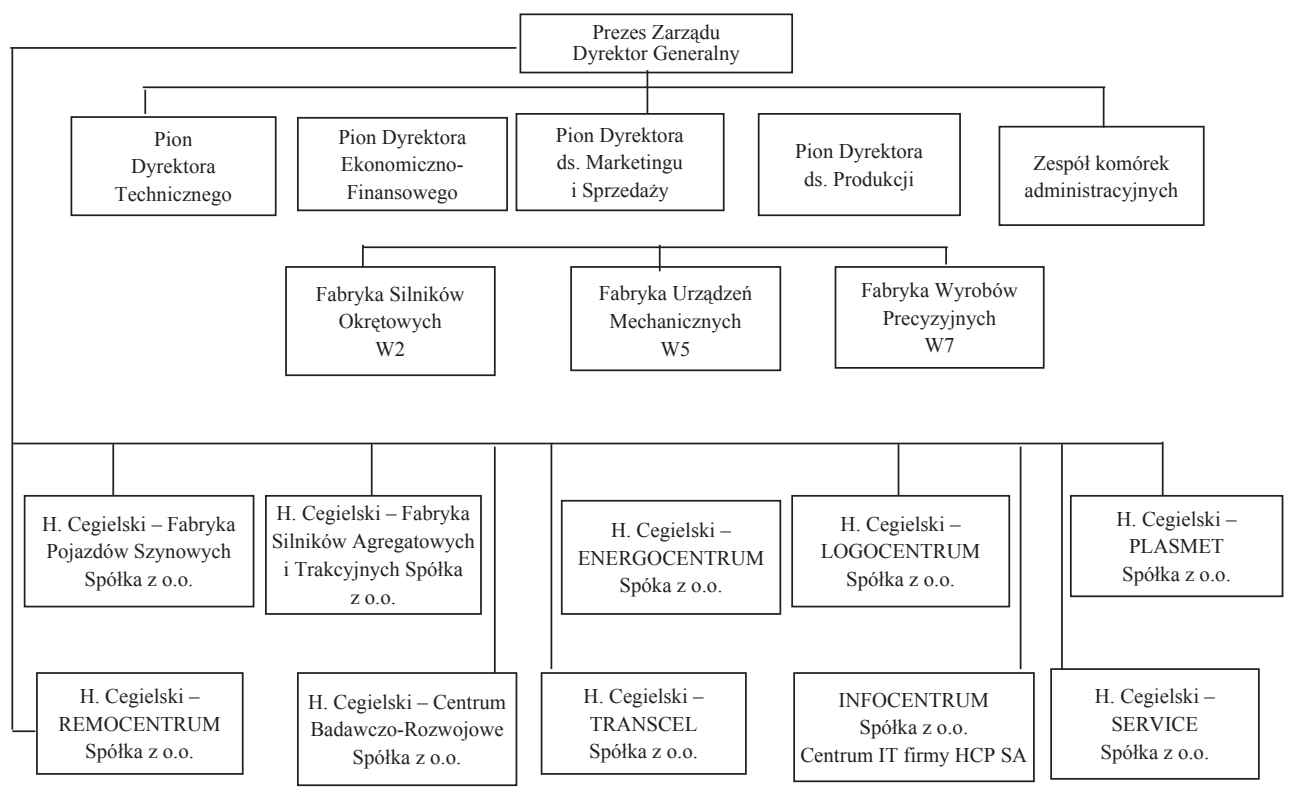

Ryc. 2. Struktura organizacyjna H. Cegielski - Poznań S.A. w 2000 roku 
Zmniejszenie wskaźników specjalizacji w analizowanych dużych przedsiębiorstwach przemysłowych $\mathrm{w}$ wyniku ich restrukturyzacji w znacznej mierze polega na eksternalizacji pewnych funkcji przedsiębiorstwa, niezwiązanych bezpośrednio z produkcją. $\mathrm{Z}$ reguły są to funkcje o charakterze pomocniczym dla produkcji, a więc np. transport czy remonty, które przekazuje się do wykonania firmom zewnętrznym. Działania takie są rezultatem niepewności producentów, którzy w sytuacji częstych zmian popytu zlecają część procesu produkcji podwykonawcom, wywołując tym samym silne korzyści zewnętrzne. Taka strategia i taki sposób funkcjonowania przedsiębiorstwa nazywany jest outsourcingiem i wynika bezpośrednio z dążenia do obniżenia kosztów działalności przedsiębiorstw.

Równocześnie $\mathrm{z}$ wprowadzaniem outsourcingu jako nowej formy funkcjonowania przedsiębiorstw przemysłowych i zarządzania nim oraz wraz z ewolucją struktur organizacyjnych na drodze autonomizacji jej jednostek następuje proces spin-offs - zakładania nowych, odrębnych firm przez pracowników opuszczających swoje przedsiębiorstwa, w wyniku likwidacji niektórych działów, komórek lub stanowisk. Powstałe spółki stają się osobnymi podmiotami gospodarczymi, świadczącymi na rzecz spółki-matki pewne funkcje na mocy zawartych z nią porozumień i umów, przy czym w początkowej fazie funkcjonowania pracują one głównie na zlecenie tych przedsiębiorstw (często głównym motywem ich powstania jest zapewnienie zleceń przez firmę-matkę przez określony okres).

Przykładem procesu spin-offs są opisane powyżej zmiany w strukturze organizacyjnej HCP (spółki wydzielone ze struktury organizacyjnej tego przedsiębiorstwa zostały założone przez byłych pracowników likwidowanych wydziałów i ich funkcjonowanie opiera się na świadczeniu usług na rzecz spółki-matki), a jednocześnie są to też przykłady outsourcingu (przedsiębiorstwo korzysta z usług wyspecjalizowanych firm zewnętrznych dla realizacji określonych zadań w procesie produkcyjnym). Innym przykładem outsourcingu moga być także zmiany organizacyjne w Fabryce Łożysk Tocznych po prywatyzacji. Szwedzki koncern SKF, który zakupił kontrolny pakiet akcji fabryki, wprowadził nową organizację w przedsiębiorstwie, zgodną z obowiązującą w całym koncernie. Wprowadzone zmiany polegały m.in. na tym, że przesunięto części funkcji poza obszar spółki, co oznacza, że niezbędne usługi będą kupowane na zewnątrz. Z fabryki wydzielono więc: spółkę narzędziową Protool, a firmom zewnętrznym, powstałym z byłych pracowników fabryki, przekazano obsługę sieci energetycznej, turbosprężarki, gazogeneratora, sprzątania, neutralizatora, transportu i obsługi cieplnej. Do wydzielenia ze spółki zostały również przeznaczone działy związane z remontami maszyn, sprawami ogólnogospodarczymi, remontami ogólnobudowlanymi i ochroną zakładu.

Również w takich przedsiębiorstwach, jak LECH czy „Witar” można zaobserwować działania charakterystyczne dla outsourcingu. Najczęściej przejawiało się to $\mathrm{w}$ zlecaniu firmom zewnętrznym dotychczasowych funkcji wewnętrznych, np. związanych z remontami, transportem czy ochroną mienia. W wielu z nich zachodzi też proces tzW. spin-offs. W obydwu wymienionych firmach eksternalizacji uległy funkcje transportowe, które zostały przekazane przez przedsiębiorstwa spółkom zewnętrznym, utworzonym przez byłych pracowników działów transportowych tych przedsiębiorstw, którzy otrzymali sprzęt w dzierżawę, bądź kupowali go na preferencyjnych warunkach.

Kolejną cechą charakterystyczną dla zachodzących zmian organizacyjnych w badanych przedsiębiorstwach są procesy koncentracji gospodarczej, zarówno wewnętrznej jak i zewnętrznej. Koncentracja wewnętrzna związana jest z autonomizacją jednostek organizacyjnych przedsiębiorstw, natomiast koncentracja zewnętrzna związana jest z integracją organizacyjną kilku samodzielnych firm w jeden organizm gospodarczy. 
W badanych dużych przedsiębiorstwach przemysłowych zaobserwowano dwa rodzaje koncentracji zewnętrznej: poprzez konsolidację oraz w drodze opanowania, co w przypadku badanych przedsiębiorstw oznaczało ich włączanie się w struktury organizacyjne zagranicznych koncernów poprzez sprzedaż kontrolnych pakietów akcji [por. Tobolska 2004: 125].

Procesy integracji organizacyjnej występujące $\mathrm{w}$ badanych przedsiębiorstwach sprawiły, że stały się one elementem współczesnej międzynarodowej przestrzeni przemysłowej i włączone zostały w sieci przemysłowe utworzone przez wielonarodowe koncerny. Jak zauważa T. Stryjakiewicz [1999] tworzenie sieci przemysłowych ma również aspekt przestrzenny, związany z ekspansją przedsiębiorstw wielonarodowych i globalizacją działalności gospodarczej.

Kolejną istotną zmianą w organizacji przedsiębiorstw jest tworzenie w strukturach organizacyjnych nowych komórek marketingowych, odpowiedzialnych za relacje z klientami oraz wzrost znaczenia marketingu w funkcjonowaniu przedsiębiorstw. Transformacja gospodarcza dała bowiem przedsiębiorstwom nowy impuls dla nowej orientacji produkcji przemysłowej, skierowanej na potrzeby rynku i klientów, co doprowadziło właśnie do intensywnego rozwoju marketingu. W okresie gospodarki centralnie sterowanej polskie przedsiębiorstwa przemysłowe wykazywały niezmienną orientację produkcyjną, tworząc tzw. rynek producenta. W przedsiębiorstwach tych uwaga kierownictwa skoncentrowana była do wewnątrz, na sprawność mechanizmu produkcyjnego. Według koncepcji ewolucji przemysłu H.I. Ansoffa [1985: 55] kolejną orientacją po tzw. produkcyjnej, związanej z okresem masowej produkcji, jest orientacja rynkowa - marketingowa, trwająca już od końca lat 30 . w gospodarce amerykańskiej, a związana z masowym marketingiem. Wzrost znaczenia marketingu w przedsiębiorstwach przemysłowych jest charakterystyczną cechą przemysłu w okresie postindustrialnym, głównie pod wpływem coraz większej złożoności otoczenia.

Podwyższenie rangi działalności marketingowej jest jedną z najwyraźniejszych zmian, która wystąpiła w strukturach organizacyjnych we wszystkich badanych przedsiębiorstwach. Wzrost znaczenia marketingu polegał przede wszystkim na utworzeniu w strukturach organizacyjnych badanych przedsiębiorstw pionów marketingowych lub komórek marketingowych w pionach handlowych. W ślad za tym nastąpiło rozbudowanie funkcji realizowanych w ramach tej działalności. Najczęściej włączano do zakresu działania funkcje analizy sytuacji konkurentów, funkcje promocji lub funkcje badania rynku, prowadzone na miarę możliwości istniejących w przedsiębiorstwach. Wzrost rangi i znaczenia funkcji marketingowych w przedsiębiorstwach wiąże się też z wprowadzeniem nowej organizacji sprzedaży (stoiska patronackie, hurtownie patronackie, agenci), zmianą zakresu działalności dystrybucyjnej, a przez to zmianą zasięgu przestrzennego funkcjonowania przedsiębiorstw. Przykładem takich zmian może być organizacja sprzedaży w „Witarze”, gdzie utworzono pewien stały układ sprzedaży w postaci kanałów dystrybucji, w celu jak największego zbliżenia towaru do klienta użytkownika (ryc. 3). Według tego schematu sprzedaż na rynek lokalny dokonuje się przez działy sprzedaży poszczególnych tartaków oraz przez składy drzewne, natomiast rynek odbiorców eksportowych jest obsługiwany przez biuro handlowe „Witaru”.

Ponadto zwiększenie zasięgu rynków zbytu przedsiębiorstw ściśle związane jest ze zwiększeniem liczby kanałów dystrybucji: w wielu przedsiębiorstwach utworzono tzw. sieci przedstawicieli regionalnych, czy też regionalne centra dystrybucji. Przykładem mogą być utworzone w „Polfie” sieci przedstawicieli regionalnych medycznych i aptecznych i obejmujących swym zasięgiem działania obszar całej Polski (ryc. 4). Utworzenie sieci przedstawicieli regionalnych było częścią nowej strategii „Polfy”, dotyczącej wzrostu udziału w sprze- 
daży leków na rynku krajowym. Tym samym struktura organizacyjna „Polfy” ewoluowała w kierunku regionalnej, w której koordynacja zarządzania zorientowana została na specyfikę poszczególnych segmentów rynku zbytu i powierzona przedstawicielom przedsiębiorstwa w wydzielonych przez nie obszarach kraju - regionach.

\section{Kanaly dystrybucji}

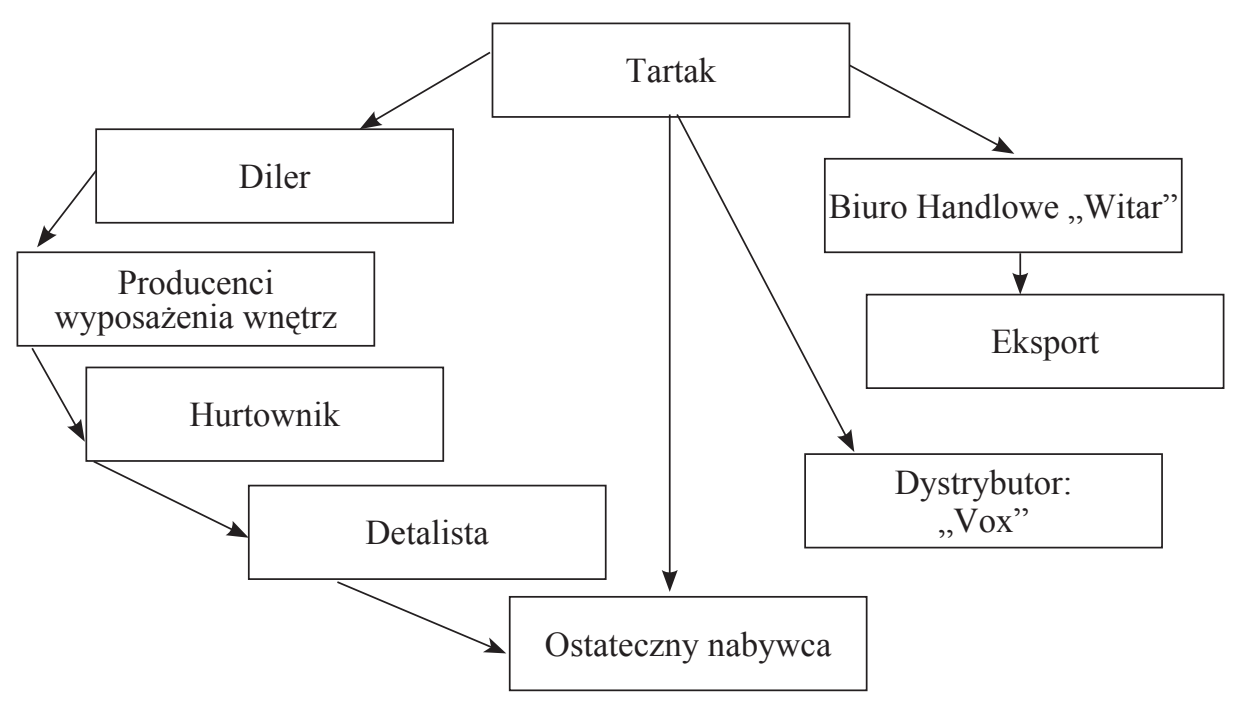

Ryc. 3. Organizacja sprzedaży w „Witarze”

Przykładem działań marketingowych zwiększających obszar zbytu produktów przedsiębiorstwa jest utworzenie centrów dystrybucji w „LECH-u” BW. Celem utworzenia regionalnych centrów dystrybucji było zdobycie jak największej liczby klientów i tym samym rozszerzenie zasięgu rynku zbytu. W przedsiębiorstwie tym do roku 1994 sprzedaż piwa i napojów odbywała się za pośrednictwem wielu indywidualnych hurtowników. W 1993 roku w spółce zaopatrywało się ok. 700 hurtowników i 500 odbiorców detalicznych, a produkcja skierowana była prawie w 70\% na teren Wielkopolski. Po wprowadzeniu zmian organizacyjnych pion marketingu rozrósł się z 15 osób w 1994 roku do 150 osób w 1996 i zmieniła się organizacja sprzedaży: zostały utworzone tzw. centra dystrybucji. Tak więc konsekwentnie realizowano główną strategię marketingową, dotarcia do jak największej liczby klientów poprzez rozbudowaną sieć dystrybucji. W wyniku tych działań zmniejszyła się liczba bezpośrednich odbiorców produktów „LECH-a” z 1200 w 1993 roku, do 64 centrów dystrybucji i hurtowni patronackich w końcu 1997 roku, ale zlokalizowanych na terenie całego kraju.

Jednym ze skutków restrukturyzacji w sferze organizacji przedsiębiorstwa są zmiany wielkości zatrudnienia, a w przypadku starych i dużych przedsiębiorstw przemysłowych, które są przedmiotem tej analizy, najczęściej jednak jego redukcja.

We wszystkich analizowanych przedsiębiorstwach nastąpił spadek wielkości zatrudnienia (ryc. 5), choć nie wszędzie wiązało się to bezpośrednio ze zmianami organizacyjnymi. Redukcje liczebności załóg w pierwszym okresie transformacji gospodarczej kraju następowały $\mathrm{w}$ większości przedsiębiorstw przemysłowych w związku ze spadkiem popytu, co związane było z zerwaniem umów z dawnymi kontrahentami, zarówno krajowymi jak 
a) przedstawiciele medyczni

b) przedstawiciele apteczni
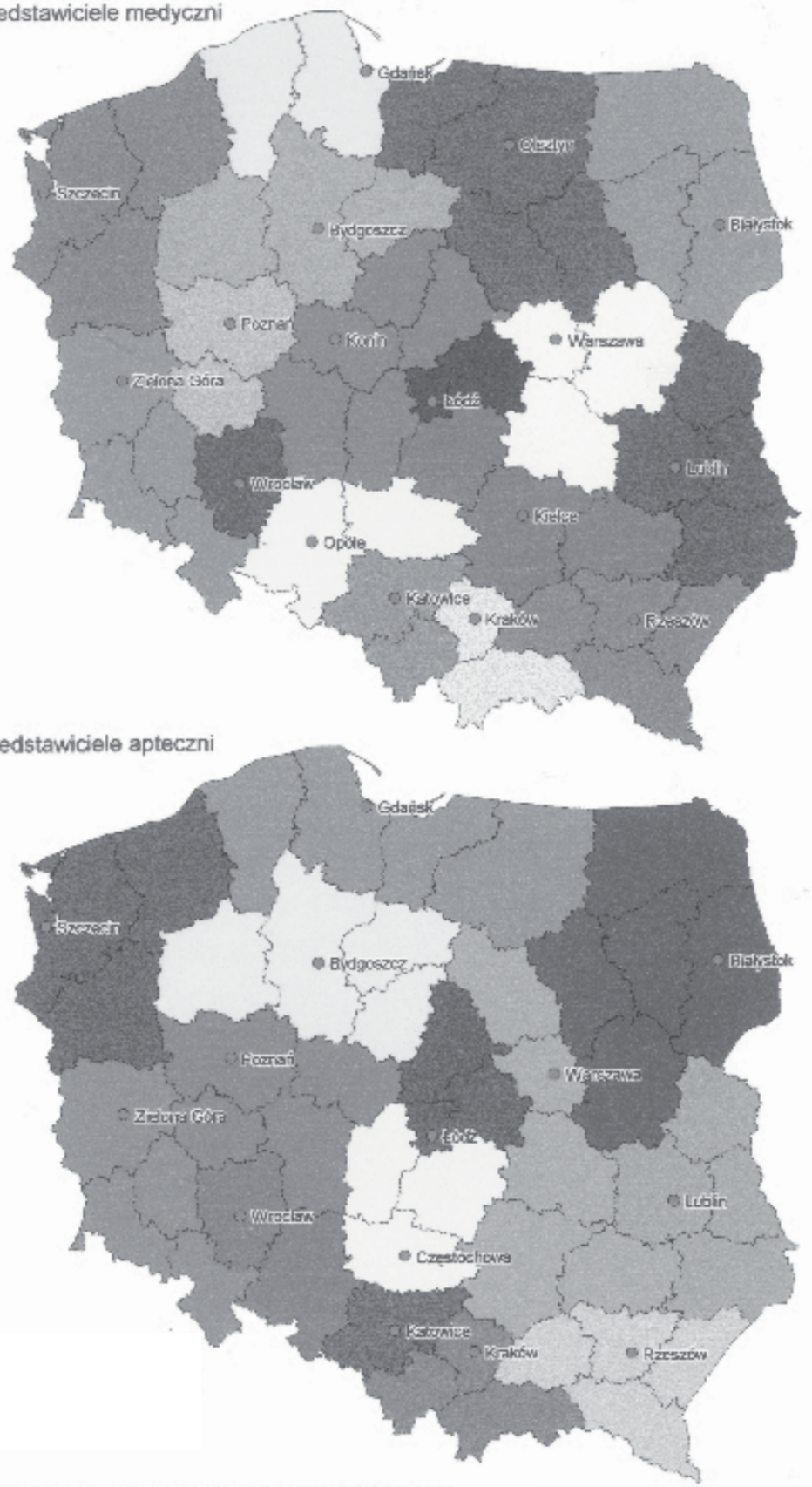

Ryc. 4. Zasięg przestrzenny działania przedstawicieli regionalnych „Polfy” S.A. (1997) Źródło: opracowanie na podstawie danych z przedsiębiorstwa 
i zagranicznymi, głównie z rozwiązanego bloku państw RWPG. Innym ważnym czynnikiem spadku popytu na wyroby polskich przedsiębiorstw przemysłowych stała się konkurencja towarów z zagranicy, często wielokrotnie tańszych i dobrej jakości. Sytuacja na rynku zmuszała przedsiębiorstwa do zmiany strategii działania, a w konsekwencji również (co potwierdza ustalenia Chandlera „Structure follows Strategy”) do zmian organizacji. To z kolei zazwyczaj wymuszało zmiany zatrudnienia. Natomiast zmiany organizacji przedsiębiorstw następowały w wielu wypadkach z chwilą zmian własnościowych, stąd też zmiany zatrudnienia związane są bardzo często z komercjalizacją i prywatyzacją. W drugim etapie transformacji na redukcję zatrudnienia wpływ wywierały również wprowadzanie nowoczesnych maszyn i technologii, mniej pracochłonnych.

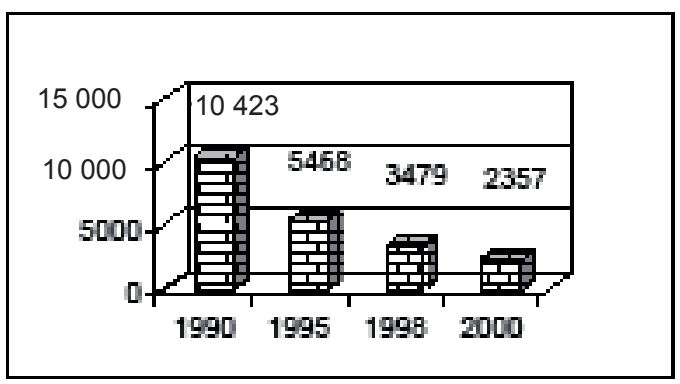

Ryc. 5. Zmiany liczby zatrudnionych w H. Cegielski Poznań S.A.

\section{NOWY MODEL FUNKCJONOWANIA PRZEDSIĘBIORSTW PRZEMYSŁOWYCH JAKO REZULTAT ZMIAN ORGANIZACYJNYCH}

Restrukturyzacja przedsiębiorstw przemysłowych, której głównym wymiarem są zmiany organizacyjne, doprowadziła głównie do uelastycznienia ich struktur, co polegało przede wszystkim na autonomizacji wewnętrznych jednostek organizacyjnych, outsourcingu i spin-offs.

Procesy outsourcingu i spin-offs mogą być uznane za jedną z cech elastycznego modelu produkcji przemysłowej [por. Domański 1992; Tobolska 2004]. Rezultatem tych procesów jest powstawanie wielu nowych małych i średnich przedsiębiorstw, które przejmują funkcje oddane na zewnątrz przez duże przedsiębiorstwa. Natomiast rezultatem przestrzennym tych procesów jest powstawanie aglomeracji przemysłowych nowego typu, z dużą ilością mniejszych firm, powiązanych ze sobą współpracą i wykonujących głównie zlecenia dużych przedsiębiorstw. Dochodzi więc do koncentracji przestrzennej firm współpracujących oraz wywołania korzyści aglomeracji.

Ponadto przestrzenny układ organizacyjny przedsiębiorstw powiększa się głównie dzięki mechanizmowi rozszerzania rynków zbytu poprzez zbliżenie przedsiębiorstwa do klienta: tworzone są nowe komórki struktury organizacyjnej w postaci sieci przedstawicieli regionalnych, czy też centrów dystrybucji. Natomiast w procesach integracji organizacyjnej następuje włączanie się przedsiębiorstw w struktury międzynarodowych koncernów, co sprawia, że przedsiębiorstwa te stają się elementem współczesnej międzynarodowej przestrzeni przemy- 


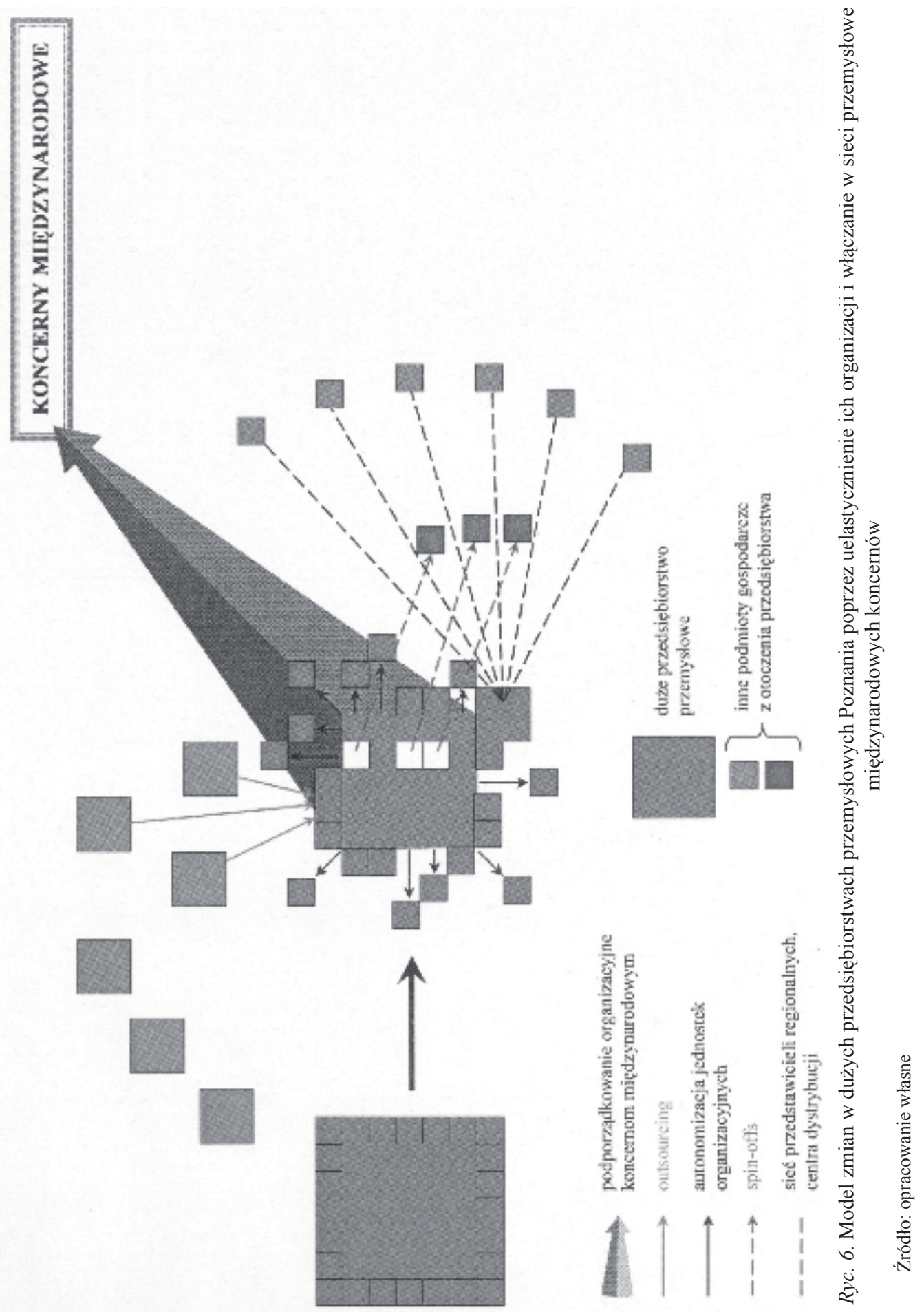


słowej i zostają włączone w sieci przemysłowe utworzone przez wielonarodowe koncerny. Model tych zmian organizacyjnych przedstawiono na ryc. 6 .

Przedstawiony model ujawnia nowe zachowania przestrzenne (spatial behaviour) dużych przedsiębiorstw przemysłowych poprzez zmianę skali przestrzennej ich dotychczasowych organizacji w procesach koncentracji wewnętrznej i zewnętrznej.

\section{Literatura}

Ansoff H.I. 1985, Zarzadzanie strategiczne, PWE, Warszawa

Domański B. 1992, Postfordowski elastyczny model produkcji a jej przestrzenna organizacja, Biuletyn KPZK PAN z. 159, Warszawa

Domański B. 1997, Geografia przedsiębiorstw - niedoceniany nurt badań w polskiej geografii ekonomicznej, [w:] Geografia, człowiek, gospodarka, red. B. Domański, A. Jackowski, Instytut Geografii UJ, Kraków

Koziński J. 1996, Struktury organizacyjne ugrupowań gospodarczych, [w:] Struktury organizacyjne przedsiębiorstw i ich ugrupowań, red. R. Krupski, M. Przybyła, Zakład Narodowy im. Ossolińskich, Wydawnictwo PAN, Wrocław-Warszawa-Kraków

Majchrzak J. 2001, Przeksztatcenia polskich przedsiębiorstw $w$ świetle zmian organizacyjnych, Akademia Ekonomiczna w Poznaniu, Poznań

Nizard G. 1998, Metamorfozy przedsiębiorstwa. Zarzqdzanie w zmiennym otoczeniu organizacji, tł. Z. Podlasiak, PWN, Warszawa [oryg. 1991]

Przybyła M. 1996, Struktury organizacyjne przedsiębiorstw, [w:] Struktury organizacyjne przedsiębiorstw i ich ugrupowań, red. R. Krupski, M. Przybyła, Zakład Narodowy im. Ossolińskich, Wydawnictwo PAN, Wrocław-Warszawa-Kraków

Sapijaszka Z. 1996, Restrukturyzacja przedsiębiorstwa. Szanse i ograniczenia, Wydawnictwo Naukowe PWN, Warszawa

Stadtherr S. 1997, O niektórych finansowych uwarunkowaniach zmian strukturalnych $w$ gospodarce, [w:] Struktury przemystowe w gospodarce. Aspekty ekonomiczne, spoleczno-kulturowe i politycz$n e$, red. L. Olszewski, J. Morzymas, Wydawnictwo Uniwersytetu Wrocławskiego, Wrocław

Stryjakiewicz T. 1999, Adaptacja przestrzenna przemystu $w$ Polsce $w$ warunkach transformacji, Wydawnictwo Naukowe UAM, Seria Geografia, 61, Poznań

Tobolska A. 2004, Zmiany własnościowe i organizacyjno-ekonomiczne w wybranych dużych przedsiębiorstwach przemystowych Poznania w okresie transformacji, Bogucki Wydawnictwo Naukowe, Poznań

\section{A new model of the organisation and operation of old industrial enterprises}

In the analysis of changes occurring in large Polish enterprises, special attention was paid to organisational changes as one of the chief aspects of their adaptation to the new economic conditions that also involves the formation of new spatial relations. The analysis makes use of the notional apparatus of the organisation and management science as a discipline concerned with changes in organisation and connected with the geography of enterprises.

To give an empirical illustration of the changes, examples are provided of the restructuring of large enterprises like H. Cegielski Poznań S.A. and LECH Browary Wielkopolski S.A. (now Kompania Piwowarska S.A.). On the basis of the empirical research, several features were distinguished to characterise the organisational changes that had taken place in the chosen industrial plants. 
The organisational changes have mainly made the structures of those plants more flexible through giving autonomy to their internal organisational units, outsourcing and spin-offs. The result has been the appearance of a lot of new small and medium-sized businesses that have taken over the functions given up by the large enterprises. The spatial effect of those changes, in turn, has been the emergence of industrial agglomerations of a new type, with a large number of smaller firms connected through a cooperation network and chiefly performing orders of the large enterprises. Thus, what we observe here is a spatial concentration of collaborating firms and the appearance of agglomeration economies.

There are also integration processes in which enterprises join the structures of international corporations, which makes them elements of the modern international industrial space and a part of the industrial networks set up by multinational firms. 